ISSN 0103-5150

Fisioter. Mov., Curitiba, v. 29, n. 3, p. 515-525, Jul./Set. 2016

Licenciado sob uma Licença Creative Commons

DOI: http://dx.doi.org.10.1590/1980-5918.029.003.A009

(c)

\title{
Effect of global postural re-education and isostretching in patients with nonspecific chronic low back pain: a randomized clinical trial
}

\section{Efeitos da reeducação postural global e do isostretching em pacientes com lombalgia crônica não-específica: ensaio clínico aleatório}

Fábio Alexandre Moreschi Guastala ${ }^{[a]}$, Mayara Hilda Guerini ${ }^{[a]}$, Patricia Fernanda Klein ${ }^{[a]}$, Vanessa Cristina Leite ${ }^{[a]}$, Renata Cappellazzo ${ }^{[a]}$, Ligia Maria Facci ${ }^{[b]^{*}}$

[a] Centro Universitário de Maringá (UNICESUMAR), Maringá, PR, Brazil

[b] Universidade Estadual de Londrina (UEL), Londrina, PR, Brazil

\begin{abstract}
Introduction: Low back pain is one of the most prevalent musculoskeletal disorders, but little is known about postural methods in its treatment. Objective: Analyze changes in muscle strength, flexibility, function and pain in patients with chronic low back pain that underwent isostretching and global posture reeducation (GPR). Methods: Thirty-nine patients, aged between 40 and 59 years, were evaluated before and after treatment protocols regarding: flexibility for sit and reach, muscle strength, functional capacity using the Rolland-Morris Questionnaire, and intensity of pain by Visual Analog Scale. The sample was randomized into two groups (1-GPR; 2-Isostretching), all of whom were treated individually through 12 sessions lasting 45 minutes each, twice a week. Results: After treatment, median reduction in pain intensity of $28 \mathrm{~mm}$ in group 1 and $32 \mathrm{~mm}$ in group 2 was observed, and a median improvement in functional capacity in group 1
\end{abstract}

*FAM: BS, e-mail: fabio.amguastala@gmail.com MHG: BS, e-mail: mayaraguerini@hotmail.com PFK: BS, e-mail: patriciafklein@hotmail.com VCL: BS, e-mail: leite.fisio@hotmail.com RC: MS, e-mail: renatacappellazzo@gmail.com LMF: PhD, e-mail: ligiafacci@uel.br 
of 8.5 points and 7 points in group $2(\mathrm{p}<0,05)$. A mean improvement of severn repetitions in trunk extensor muscle strength was observed in group 1 and in group 2; by dynamometry of $10 \mathrm{~kg} / \mathrm{f}$ in group 1 and $12.5 \mathrm{~kg} / \mathrm{f}$ in group 2 of ten abdominal repetitions strength in group 1 and four repetitions in group 2 (p $<0.05$ ). In the Sit and Reach, Group 1 had a total mean increase of $3 \mathrm{~cm}$, and group 2 had $1.6 \mathrm{~cm}$ ( $\mathrm{p}<0.05$ ). Conclusion: Both groups were effective in improvement of muscle strength, flexibility, pain and functional capacity.

Keywords: Posture. Rehabilitation. Low Back Pain. Spine. Exercise Therapy.

\section{Resumo}

Introdução: A lombalgia é uma das mais prevalentes disfunções musculoesqueléticas, porém pouco se sabe sobre os métodos posturais no seu tratamento. Objetivo: Analisar as alterações de força muscular, flexibilidade, função e dor em pacientes com lombalgia crônica submetidos à Reeducação Postural Global (RPG) e Isostretching. Métodos: Trinta e nove pacientes com idade entre 40 e 59 anos foram avaliados antes e após os protocolos de tratamento quanto à flexibilidade pelo teste Sentar e alcançar, força muscular, capacidade funcional pelo Questionário Rolland-Morris e intensidade da dor pela Escala Visual Analógica. A amostra foi aleatorizada em dois grupos (1-RPG; 2-Isostretching), sendo todos tratados individualmente através de 12 sessões de 45 minutos, duas vezes por semana. Resultados: Foi observada mediana de redução na intensidade da dor de $28 \mathrm{~mm}$ no grupo 1 e de $32 \mathrm{~mm}$ no grupo 2; e melhora mediana na capacidade funcional no grupo 1 de 8,5 pontos e de 7 pontos no grupo $2(p<0,05)$. Observou-se mediana de melhora de 7 repetições na força muscular extensora de tronco no grupo 1 e no grupo 2; na Dinamometria de $10 \mathrm{~kg} / \mathrm{f}$ no grupo 1 e de $12,5 \mathrm{~kg} / \mathrm{f}$ no grupo 2; de 10 repetições da força abdominal no grupo 1 e 4 repetições no grupo $2(p<0,05)$. No teste Sentar e Alcançar o grupo 1 obteve aumento médio de $3 \mathrm{~cm}$ e o grupo 2 de 1,6 cm ( $p<0,05)$. Conclusão: Ambos os grupos foram efetivos na melhora de força muscular, flexibilidade, da dor e da capacidade funcional.

Palavras-chave: Postura. Reabilitação. Dor Lombar. Coluna Vertebral. Terapia por Exercício.

\section{Introduction}

A complaint of low back pain, with or without radiation to the lower limbs, is the second most common reason that leads workers to seek health care (1). Vitta (2) states that low back pain affects people in different stages of life, thereby, translating into a disease that causes important socioeconomic impact (1).

There is significant evidence supporting exercises in the treatment of non-specific low back pain (3). These exercises allow patients to acquire flexibility and stability of the lumbar spine, aiming to prevent painful recurrences (4). The effectiveness of specific types of exercises, however, still needs to be evaluated in further studies with an appropriate methodology (5).

Despite the lack of scientific studies, indications of postural exercises are common in clinical practice, especially the isostretching method and global postural re-education (GPR) for treatment of patients with chronic low back pain.
The isostretching, global postural exercise method, which emphasizes the strengthening of the deep muscles through isometric contraction, is a technique that stimulates the corporeal awareness and the acquisition of good physical condition (6). The application of this method has been studied for different purposes, such as: evaluating respiratory consequences in healthy individuals (7), optimization of skills in athletes (8), improvement of gait (9) and balance $(10,11,12)$, functional capacity in the elderly $(12,13)$, hamstring flexibility (14), posterior chain muscles (15), the benefits in patients with shoulder impingement syndrome (16) and mastectomy (17). Still, with respect to specific applications in postural re-education, studies were found with this technique in the treatment of idiopathic scoliosis $(18,19,20,21)$ and thoracic kyphosis (22).

Some research was conducted to investigate the application of isostretching in patients with low back pain $(23-27)$. These studies showed improved functional capacity (23 - 27) of muscular 
endurance (26), flexibility $(23,24)$ and reduction in pain intensity $(23-25)$. However, in addition to the great methodological diversity employed in these studies, when isostretching is compared with conventional kinesiotherapy, no significant differences were identified (25).

Global postural re-education (GPR) is the application of isometric exercise by maintaining static postures (28). This method emphasizes that the tension on a muscle group can reflect on changes and compensation in the entire chain (29). Thus, this technique aims to correct muscle compensation, dealing with the cause to the effect (30). With the wide spread adoption of this method, which was created by Philippe Emmanuel Souchard in 1987 (28), studies were stimulated that would substantiate justification of its application. Some research highlighted the benefits of the GPR in patients with spinal pain (31), in postural changes (31 - 33), flexibility improvement $(29,34,35)$, increased range of motion $(29,34)$ muscle strength $(29)$, functional capacity (36), and reduction of the intensity of pain (36) and stiffness (35).

Some case studies using the GPR postures in patients with low back pain were found. Eduardo et al. (37) investigated ten patients with low back pain who underwent GPR, finding significant improvement in quality of life and reduction in pain intensity. Heredia and Rodrigues (36) applied the GPR in 18 patients with epidural fibrosis in the postoperative period for herniated discs, observing an increase of amplitude of the coxofemoral, functional ability and reduction in pain in $56.25 \%$ of patients. Also in patients with lumbar disc herniation, Di Ciaccio et al. (38) applied GPR in 24 patients, and found a reduction in pain intensity and improvement in functional capacity.

In a randomized clinical trial, Bonetti et al. (39) evaluated the efficacy of a GPR program compared with stabilization exercises in patients with chronic low back pain in the short and medium term. This study showed that the individuals of the GPR group had significant improvement in pain and functional capacity in relation to the spinal stabilization group.

Considering that the GPR and isostretching methods are often applied in clinical practice, despite the lack of evidence to support it, especially in the treatment of patients with low back pain, this study is justified.

The aim of this research was to investigate changes in the flexibility, muscle strength, functional capacity and pain intensity in patients with chronic low back pain undergoing GPR and isostretching, and to compare the results obtained from these methods.

\section{Methods}

A single-blind randomized clinical trial was performed, after approval was received from the Research Ethics Committee (CEP) of Centro Universitário de Maringá-PR (UNICESUMAR), protocols no. 237/2010 and 248/2010, according to the Resolution MS/CNS No. 196/96 of the Ministry of Health (MOH).

After evaluation of the referral records of people with nonspecific chronic low back pain at the physiotherapy clinic at UNICESUMAR, patients received phone calls, were informed of the research objectives, questioned about inclusion and exclusion criteria, and were invited to participate in the study. Those who agreed to participate signed a consent form.

In order to be included in the study, patients had to be: 40 to 60 years old, referred to the physiotherapy clinic at UNICESUMAR with a medical prescription with the description of nonspecific low back pain. Patients with incompatible schedules for visits, lack of transportation, a disease that compromised their health during treatment and/or the study results, namely uncontrolled hypertension, fibromyalgia, spinal surgery in the previous six months, disc herniation, spondylolisthesis, neurological disorders, and inability to perform or to understand physical exercise were excluded.

Before and after implementation of treatment protocols, all patients were evaluated by an, independent examiner, namely, one that had no knowledge about the intervention, regarding different variables. Assessment of pain intensity was performed using the pain Visual Analogue Scale (VAS) (40); functional capacity was assessed using the Roland-Morris Questionnaire (RMQ) (41); flexibility was assessed using the Sit and Reach test (42); Dinamometry was used to evaluate the muscle strength of trunk extensors (43), with the device BACK - A, TYPE - 2, and the Maximum Repetition test in a minute - MR, which was also applied to assess abdominal muscle strength (26). Postural analysis was also applied based on the concepts of muscle chains (44) for choosing the therapeutic postures.

The VAS is a $10-\mathrm{cm}$ line, numbered from zero to ten, where zero corresponds to absence of pain and 
ten to the maximum intensity of pain, with the information provided by the volunteer himself (40).

The tool for the assessment of low back pain, specific inability, the Roland-Morris Questionnaire, allows for evaluation of the physical limitations resulting from such pain on the lumbar spine and has been used to assess limitations arising from it. It consists of 24 questions, each statement corresponds to one point, and the final score is determined by the sum of the obtained values. Values close to zero represent the best results, namely a lower limitation, and values close to 24 correspond to the worst results, or a higher limitation (41).

The MR of trunk extensor was performed with the patient in the prone position, with hands positioned in the occipital region, support in the frontal region and fixation of the pelvis by the therapist to perform the movements. Then, the therapist asked the patient to demonstrate his maximum trunk extension, by analyzing the amplitude, and then the patient performed the largest number of movements of the same amplitude in one minute. The abdominal MR was performed with the patient supine with bent and stabilized legs, arms crossed in the anterior chest region, and then the therapist asked the patient to perform the largest number of trunk flexions in a minute (26).

For dynamometry of trunk extensors the patient remained standing under the dynamometer, with the legs in knee extension and trunk in anterior inclination of $120^{\circ}$. In this position, the patient held the dynamometer bar with elbow extension, and then the therapist requested that the patient perform an extension of the trunk with specific action of the lumbar muscles for six seconds, by positioning the trunk closest to an erect posture (43).

After being evaluated by the physiotherapist, patients were randomly assigned through computergenerated numbers to both treatment groups. After generation of numbers, they were transformed into a card with the assigned treatment (GPR -1, isostretching - 2) and then placed in sealed, opaque envelopes numbered in sequence. This prevented the evaluator and the therapist from choosing the group to which the patient would be assigned.

All patients were monitored individually, and performed a therapeutic program of 12, 45-minute sessions twice a week. The GPR group performed three positions of the method per session, held for 15 minutes each, in order to make for more uniform treatment and reduce variability between sessions. The isostretching group performed nine postures, which were held for a period of nine breaths each, and the patient rested for 60 seconds every three cycles. To perform some isostretching postures, a bat and a ball were used as auxiliary instruments.

The choice of postures in both methods was determined by prior postural analysis, which detected the predominance of muscle chains. Postural changes designating retraction of the previous chain were: anterior head, dorsal kyphosis, lumbar hyperlordosis, pelvic anteversion, valgus knees and ankles, and flat feet. Postural changes demonstrating retraction of the posterior chain detected in the initial examination were: cervical lordosis, dorsal rectification, lumbar hyperlordosis, pelvic tilt, varus knees and ankles and pes cavus. If the sum of changes determined predominance of an anterior string, the postures were performed by opening the angle of the coxofemoral articulation, which are in a neutral position related to the hip joint and can be performed with the patient standing or lying down. If the sum of changes determined prevalence of a posterior chain, the postures were performed by closing the coxofemoral angle, which is performed with the hip joint flexed and can be performed with the patient standing, sitting or lying (44). Equal changes in both chains were named mixed muscle chain retractions. The chosen treatment postures therefore were also intercalated between open and closed coxofemural.

Considering the degree of difficulty of each patient and predominance of muscle chains, different postures were performed with each patient. At the beginning, at the end, and every 15 minutes of care, the heart rate, blood pressure and oxygen saturation were measured for general patient management.

After treatment the patients were reassessed and the information collected was statistically analyzed using the Statistical Program for the Social Sciences (SPSS), version 18.0 with, the results considered significant with $\mathrm{p}>0.05$.

For the analysis of data distribution, the ShapiroWilk test was used. Because the data were not normally distributed, the median (Md) and quartiles (Q1, Q3) were used to characterize the quantitative results. Frequencies and percentages were used for categorical data. The "U" Mann-Whitney test was used to compare the treatment methods; for the association between variables the chi-square test 
was used; for the comparison of the variables before and after treatment within groups, the Wilcoxon test was used.

\section{Results}

One hundred and three patients with chronic low back pain, waiting for consultation in the
Physiotherapy Clinic of UNICESUMAR, were selected. Sixty patients were excluded from the sample for different reasons, four withdrew from treatment and were not reevaluated. Among the dropouts, only one was due to change of address, not being able to be evaluated (Figure 1). Among the thirty-nine patients with chronic back pain who completed the protocol, 21 were randomly assigned to group 1 (GPR) and 18 to group 2 (isostretching).

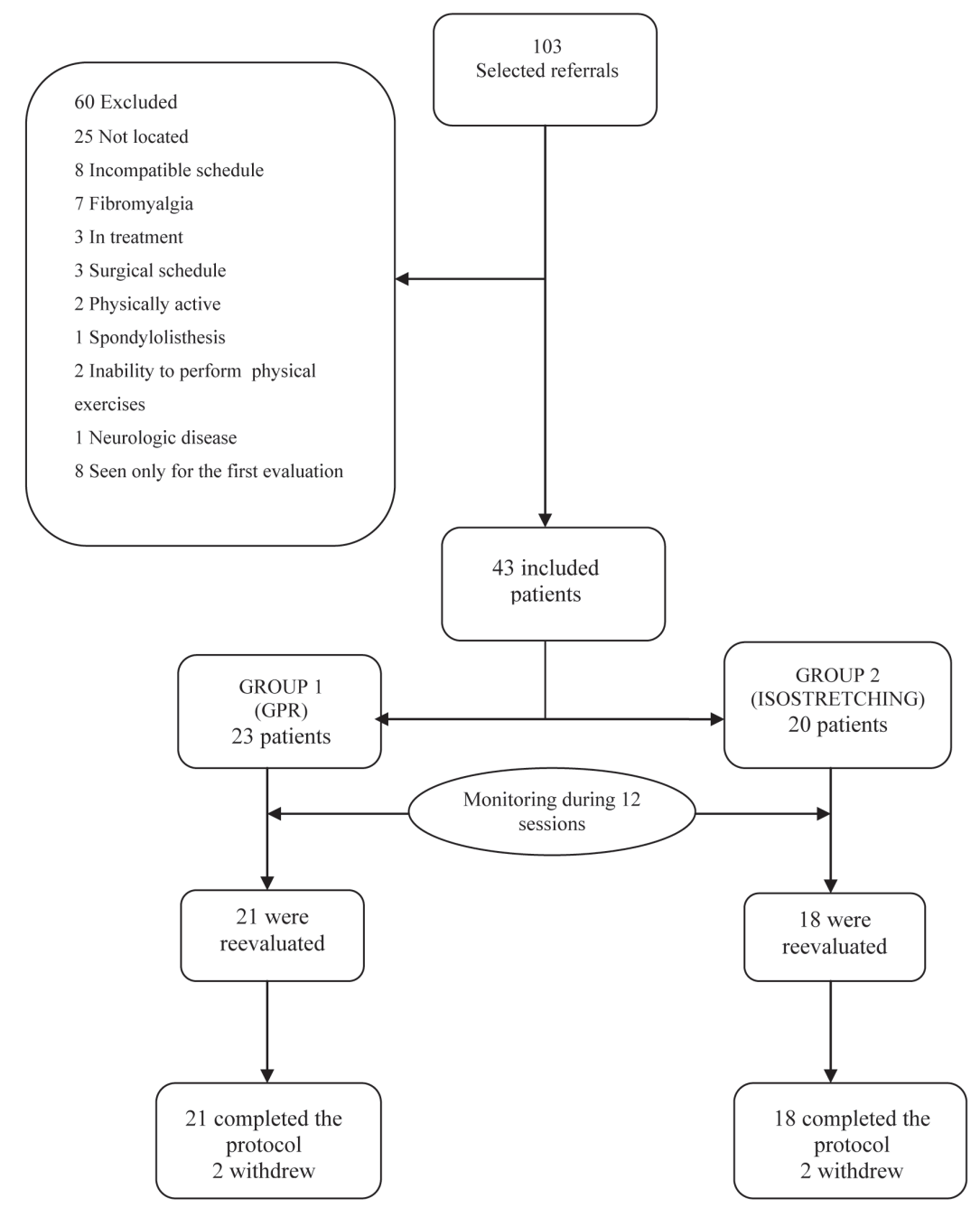

Figure 1 - Diagram of the distribution of study patients.

Regarding the patients in group 1, three were male and 15 were female; 15 were married, two were single and one was a widower. Among the most prevalent occupations in this group were, seven housekeepers and two seamstresses. Most of the patients in group $1(50 \%)$ predominantly presented retraction of the previous chain muscles. In group 2 , five individuals were male and 16 were female; 16 were married, three were single and two were divorced; five were housekeepers and two were seamstresses. Regarding the prevalent muscle chain at initial assessment, 61\% of members of group 2 presented a predominance of retraction of the previous chain muscles.

The patients in groups 1 and 2 were homogeneous ( $p>0.05$ ) with respect to the complaint time, age, pain, functional capacity, muscle strength and flexibility (table 1) at the beginning of the study, using the "U" Mann-Whitney test. 
Table 1 - Initial characteristics of patients included in the study

\begin{tabular}{|c|c|c|c|}
\hline \multirow[t]{2}{*}{ Variables } & $\begin{array}{c}\text { Global Postural } \\
\text { Re-education (GPR) } \\
(n=21)\end{array}$ & $\begin{array}{l}\text { Isostretching } \\
\qquad(\mathrm{n}=18)\end{array}$ & \multirow[t]{2}{*}{$\mathbf{P}$} \\
\hline & $\operatorname{Md}(Q 1 ; Q 3)$ & $\operatorname{Md}(Q 1 ; Q 3)$ & \\
\hline Age (years) & $50.50(44.00 ; 57.25)$ & $52.00(43.50 ; 54.50)$ & 0.856 \\
\hline Complaint time (months) & $102.00(60.00 ; 246.00)$ & $60.00(108.00 ; 24.00)$ & 0.133 \\
\hline Initial VAS (mm) & $45.50(34.50 ; 64.25)$ & $46.00(25.00 ; 60.50)$ & 0.666 \\
\hline Initial RMQ (points) & $12.00(9.75 ; 16.50)$ & $13.00(8.00 ; 16.50)$ & 0.922 \\
\hline Sit and Reach test (cm) & $22(17 ; 29.25)$ & $26.4(20.37 ; 31.47)$ & 0.210 \\
\hline MR of abdominal (repetitions) & $23(16.5 ; 33)$ & $22(20 ; 34.25)$ & 0.507 \\
\hline MR of trunk extensor (repetitions) & $33(22 ; 43.50)$ & $30(20.75 ; 34.25)$ & 0.498 \\
\hline Dynamometry (Kg/f) & $42(34 ; 54.50)$ & $39.5(19.75 ; 62.25)$ & 0.310 \\
\hline
\end{tabular}

Note: Significant difference ( $<$ 0.05) - Test “U” Mann-Whitney; VAS: Visual Analogue Scale; RMQ: Roland-Morris Questionaire.

As shown in Table 2, when the intensity of the initial and final pain are compared within groups, the group of patients undergoing GPR ( $p=0.001)$ and the isostretching group $(\mathrm{p}=0.000)$, presented $\mathrm{a}$ statistically significant reduction, but without statistically significant differences between the methods $(\mathrm{p}=0.494)$.
In the analysis of the functional capacity changes (Table 2), a statistically significant improvement was found in patients treated with GPR $(p=0.000)$ and Isostretching $(\mathrm{p}=0.000)$. Comparing both groups, however, a statistically significant difference was not observed $(p=0.192)$.

Table 2 - Comparison of pain intensity and functional capability (initial and final) between the two treatment groups

\begin{tabular}{|c|c|c|c|c|c|c|}
\hline \multirow[t]{2}{*}{ Variables } & \multicolumn{2}{|c|}{$\begin{array}{l}\text { Global Postural Re-education } \\
\text { (GPR) }\end{array}$} & \multicolumn{4}{|c|}{ Isostretching } \\
\hline & $\begin{array}{c}\text { Initial } \\
\text { Md }(Q 1 ; Q 3)\end{array}$ & $\begin{array}{c}\text { Final } \\
\operatorname{Md}(Q 1 ; Q 3)\end{array}$ & p & $\begin{array}{c}\text { Initial } \\
\text { Md }(Q 1 ; Q 3)\end{array}$ & $\begin{array}{c}\text { Final } \\
\operatorname{Md}(Q 1 ; Q 3)\end{array}$ & p \\
\hline $\begin{array}{l}\text { Pain intensity } \\
(\mathrm{mm})\end{array}$ & $\begin{array}{c}45.50 \\
(34.50 ; 64.25)\end{array}$ & $\begin{array}{c}17.50 \\
(0.0 ; 25.50)\end{array}$ & $0.00 *$ & $\begin{array}{c}46.00 \\
(25.00 ; 60.50)\end{array}$ & $14.00(6.00 ; 36.50)$ & $0.000 *$ \\
\hline $\begin{array}{l}\text { Funtional } \\
\text { capacity (points) }\end{array}$ & $\begin{array}{c}12.00 \\
(9.75 ; 16.50)\end{array}$ & $\begin{array}{c}3.50 \\
(1.75 ; 7.00)\end{array}$ & $0.00 *$ & $\begin{array}{c}13.00 \\
(8.00 ; 16.50)\end{array}$ & $\begin{array}{c}6.0 \\
(2.50 ; 10.50)\end{array}$ & $0.000 *$ \\
\hline
\end{tabular}

Note: Significant difference $(p<0.05)$ - Wilcoxon test.

Table 3 shows the results of muscle strength and flexibility analysis of the two groups. Regarding the muscle strength, analyzed via the MR test for abdominal, MR test for trunk extensors and dynamometry of trunk extensors, both groups were effective in improving in all these analyses. Likewise, in the analysis of flexibility test, both groups effectively improved in the Sit and Reach test when comparing ratings before and after treatment. Regarding the muscular strength changes and flexibility using the Mann-Whitney test, there were no statistically significant differences in any of these variables were comparing the two methods ( $p>0.05)$. 
Table 3 - Initial and final comparison between the two treatment groups

\begin{tabular}{|c|c|c|c|c|c|c|}
\hline \multirow[t]{2}{*}{ Variables } & \multicolumn{2}{|c|}{$\begin{array}{l}\text { Global Postural Re-education } \\
\text { (GPR) }\end{array}$} & \multicolumn{4}{|c|}{ Isostretching } \\
\hline & $\begin{array}{c}\text { Initial } \\
\text { Md (Q1; Q3) }\end{array}$ & $\begin{array}{c}\text { Final } \\
\text { Md (Q1; Q3) }\end{array}$ & $\mathrm{p}$ & $\begin{array}{c}\text { Initial } \\
\text { Md }(Q 1 ; Q 3)\end{array}$ & $\begin{array}{c}\text { Final } \\
\text { Md }(Q 1 ; Q 3)\end{array}$ & p \\
\hline Dynamometry $(\mathrm{Kg} / \mathrm{f})$ & $\begin{array}{c}42 \\
(34 ; 54.50)\end{array}$ & $\begin{array}{c}52 \\
(41 ; 66)\end{array}$ & 0.002 & $\begin{array}{c}39.5 \\
(19.75 ; 62.25)\end{array}$ & $\begin{array}{c}52 \\
(34.25 ; 78)\end{array}$ & 0.000 \\
\hline $\begin{array}{l}\text { MR of Abdominals } \\
\text { (repetitions) }\end{array}$ & $\begin{array}{c}23 \\
(16.5 ; 33)\end{array}$ & $\begin{array}{c}33 \\
(22 ; 39)\end{array}$ & 0.001 & $\begin{array}{c}22 \\
(20 ; 34.25)\end{array}$ & $\begin{array}{c}27 \\
(20.75 ; 46.25)\end{array}$ & 0.007 \\
\hline $\begin{array}{l}\text { MR of trunk extensors } \\
\text { (repetitions) }\end{array}$ & $\begin{array}{c}33 \\
(22 ; 43.50)\end{array}$ & $\begin{array}{c}40 \\
(27 ; 46)\end{array}$ & 0.003 & $\begin{array}{c}30 \\
(20.75 ; 34.25)\end{array}$ & $\begin{array}{c}27 \\
(20.75 ; 46.25)\end{array}$ & 0.001 \\
\hline Sit and Reach test $(\mathrm{cm})$ & $\begin{array}{c}22 \\
(17 ; 29.25)\end{array}$ & $\begin{array}{c}25 \\
(21.5 ; 30)\end{array}$ & 0.006 & $\begin{array}{c}26.4 \\
(20.37 ; 31.47)\end{array}$ & $\begin{array}{c}28 \\
(24.87 ; 31.5)\end{array}$ & 0.039 \\
\hline
\end{tabular}

\section{Discussion}

Spinal pain, especially in the lumbar region, often has postural changes as a cause or consequence. That is because the structures that make up the spine are in a functional and physiologically inadequate position, thereby causing pain, discomfort and functional restriction (45).

Although the literature states that most patients have nonspecific low back pain (46), it was difficult to select patients in this study, considering that many of the medical referrals were not clear, thereby preventing patient selection.

The minor number losses in this study, less than $10 \%$, is acceptable; however an intention-to-treat analysis was not performed. It should also be noted that one of the difficulties of patient compliance with the 12 sessions of the proposed methods was that, with the reduction in the intensity of low back pain, they wanted to stop treatment early.

Kinesiotherapy is one of the most frequently applied interventions in the treatment of patients with low back pain in clinical practice, through stretching programs and programs of active, resistive and proprioceptive exercises (24). The postural reeducation methods are included in this therapy.

In the present study, the proposed objectives were achieved; statistically significant results were obtained regarding reduction in pain intensity, improvement in functional capacity and abdominal muscle and trunk extensor strength, and improved flexibility in the implementation of the two postural re-education methods. No studies were found that compared the performance of
GPR and isostretching methods in patients with chronic low back pain, which makes it difficult to compare the findings.

Mann et al. (24) compared the performance of ten isostretching sessions in ten college students with low back pain with ten asymptomatic students in a control group. The analysis of pain intensity by VAS showed that isostretching was effective in reducing pain and improving flexibility, superior to the control group. An analgesic effect was also found in this study.

Durante \& Vasconcelos (25) also analyzed the variations in pain intensity and functional capacity in six women with chronic low back pain, comparing the isostretching method with conventional kinesiotherapy. Treatment of patients in group 1, consisting of just three individuals, included ten isostretching sessions twice a week, lasting 30 - 45 minutes per session. Group 2, also consisting of three individuals, performed stretching exercises of the major muscle groups with a duration of thirty seconds for each group. Both treatment groups were effective in improving pain intensity, with no difference between interventions, results that are similar to those in the present study.

Lopes et al. (23) had 20 patients with chronic low back pain undergo 12 isostretching sessions three times a week, 11 women and nine men. The isostretching protocols were similar. Statistically significant benefits in regard to reducing pain intensity in patients with low back pain were found, which was similar to the findings of the present study.

In a randomized clinical trial, Macedo et al. (26) treated nine patients with isostretching and compared them with a control group of six patients. All patients 
were female, aged between 18 and 25 years, and had chronic back pain and impaired functional capacity. The Rolland Morris questionnaire and the VAS were also applied, improvement in functional ability and reduction of pain were found in the active group of patients, similar to the findings of the present study.

Similar to the present study, in addition to these mentioned findings, Macedo et al. (26) also found a statistically significant difference in improved abdominal strength, trunk and gluteal extension when compared to the control group. Strength gain favors stability of the spine joints, which will support the resolution of the condition and prevention of relapses.

Thomé et al. (27) conducted a study comparing conventional physiotherapy (electrotherapy, massage therapy and flexibility exercise) and combined kinesiotherapy (isostretching and aquatic sensory \& motor training) for the treatment of patients with specific and nonspecific low back pain. Despite the benefits in the combined kinesiotherapy group, which included isostretching, the respiratory strength and functional capacity and the addition of another intervention and different assessment tools make it difficult to compare their results with the findings of this study?

Considering the previous studies that applied the isostretching method in patients with chronic low back pain (23 - 27), there is a need to improve the methodology by giving priority to comparative studies with larger samples.

There are few studies investigating GPR in patients with chronic low back pain. Moreira \& Soares (47) treated five women, aged 20 to 30 years, with postural changes and related pain complaints with application of the GPR postures, "floor frog" and "ballerina", over four months. There was an improvement in posture, body symmetry, in addition to a decrease in pain intensity, such as was demonstrated in the present study. A durability of the effects provided by the method was also found, given that all patients were satisfied with the performed treatment four months after therapeutic discharge. This variable was not analyzed in the present study, which emphasizes the need for further patient follow-up in future studies.

Heredita \& Rodrigues (36) applied the RolandMorris' functional capacity questionnaire and the VAS to evaluate 18 patients with lumbar disc herniation who had postoperative epidural fibrosis. Fifteen GPR sessions were performed once a week, about 50 minutes each. In this study, the GPR method was effective in improving quality of life, independence in activities of daily living, and especially in reducing the painful situation, as expressed in this study. However, it is difficult to compare these results with the findings of the present study, because all patients in the Heredita and Rodrigues study (36) had a diagnosis of specific low back pain and had previously undergone a surgical procedure.

Bonetti et al. (39) evaluated 78 patients with low back pain regarding pain intensity by VAS and functional capacity by the Roland-Morris Questionnaire. Fortytwo of these patients underwent three GPR postures, maintained for 15 - 20 minutes, whereas 36 underwent conventional stretching in ten sessions, twice a week, for one hour each. The patients were evaluated again after three and six months, a procedure that was not performed in this study. The improvement in pain intensity and functional capacity with the GPR in Bonetti et al.'s study (39) corroborates the findings of this study, but it should be noted that these authors used conventional stretching for comparison, whereas this method was not superior to isostretching in the present study.

The follow-up time of the present study was incomplete because it evaluated patients only before and after the interventions. Future studies are should evaluate again after three and six months to confirm the persistence of the effects of interventions.

In the present study, postures were applied based on retractions found in the initial evaluation. Bonetti et al.'s GPR protocol (39) included only the coxo-femural angle closure, because these are the most common retractions in the population. This statement disagrees with the present study, in which changes in both chains were found, with the former chain being prevalent in $61.9 \%$ of patients in the GPR group and 50\% in the isostretching group.

In order to analyze the changes in electromyographic responses of the latissimus dorsi muscles, upper trapezius and lower trapezius, Veronesi Junior \& Tomaz (33) applied five consecutive GPR sessions with a mean duration of 30 minutes. At the end of treatment, these authors found that the electromyographic responses of all tested muscles improved, showing gains in muscle strength. Thus, the importance of GPR practice is highlighted, which will favor postural correction through isometric contraction of the muscles responsible for maintaining the upright spine position.

Rosário et al. (29) submitted 33 women, 21 to 30 years old, to eight, 30-minute GPR sessions and segmental stretching. These authors obtained improved flexibility, as assessed by goniometry and the third finger-ground test, and muscle strength, as assessed 
by hamstring dynamometry. Both techniques achieved significant results compared to the control group, reinforcing the results of this study. In the present study, however, despite the findings corroborating Rosario et al.'s (29), there was no statistically significant difference when comparing the results of both methods.

The analysis of muscle strength of this study also showed statistically significant results. These results agree with those of Macedo et al. (26), who administered 20 isostretching sessions with nine female patients with low back pain, given that both showed a statistically significant improvement in the strength of trunk extensors. These results also agree with findings of Rosary et al. (29), which showed improved muscle strength in ten women with eight RPG sessions, where postures were administered in the coxo-femoral angle opening and closure.

One of the major differences between isostretching and GPR is the combination of manual therapy in the second method. Thus, it should be noted that professional training is essential for good patient response to treatment. Yet, despite this study directing the choice of exercises to the individual analysis of patients, it is necessary to point out that standardization for research does not characterize the ideal professional reality, where the protocol can and should be modified according to the daily patient's response to treatment.

The need for further research is emphasized to compare RPG and isostretching in treating patients with nonspecific chronic low back pain.

\section{Conclusions}

In this study, the global postural re-education (GPR) and isostretching methods were effective in reducing pain intensity, improving functional capacity, flexibility and muscle strength in patients with chronic low back pain. No statistically significant differences were found among the three methods. Therefore, further studies should be performed with bigger samples for better understanding of the benefits provided by isostretching and GPR, especially in individuals with complaints of back pain.

\section{References}

1. van Tulder M, Koes B, Bombardier C. Low back pain. Best Pract Res Clin Rheumatol. 2002;16(5):761-75.
2. Vitta A. A lombalgia e suas relações com o tipo de ocupação, com a idade e o sexo. Rev Bras Fisioter. 2001;1(2):67-72. Portuguese.

3. Hayden J, van Tulder MW, Malmivaara A, Koes BW. Exercise therapy for treatment of non-specific low back pain. Cochrane Database of Systematic Reviews. Cochrane Database Syst Rev. 2005;(3):CD000335.

4. Greve MDG, Amatuzzi MM. Medicina de reabilitação nas lombalgias crônicas. São Paulo: Roca; 2003. p. 192 - 7. Portuguese.

5. Airaksinen O, Brox JI, Cedraschi C, Hildebrandt J, Klaber-Moffett J, Kovacs F, et al. European Guidelines for the management of chronic nonspecific low back pain. Eur Spine J. 2006;15 Suppl 2:S192-300.

6. Redondo BA. Isostretching: A ginástica da coluna. Rio de Janeiro: Skin Direct Store; 2001. Portuguese.

7. Brandt AC, Ricieri DV, Griesbach LE. Repercussões respiratórias da aplicação da técnica de Isostretching em indivíduos sadios. Fisioter Bras. 2004;5(2):10310. Portuguese.

8. Prado ALC, Fonseca PHS, Rodrigues CO, Vanz F. O método Isostretching na otimização das aptidões para a prática do futebol de campo. Saude (Santa Maria). 2004;30(1-2):57-64. Portuguese.

9. Sanglard RC, Pereira JS. A influência do Isostretching nas alterações dos parâmetros da marcha em idosos. Fisioter Bras. 2005;6(4):255-60. Portuguese.

10. Sanglard RC, Pereira JS, Henriques GRP, Gonçalves GB. A influência do Isostretching nas alterações do equilíbrio em idosos. R. Bras. Ci. e Mov. 2007;15(2):6371. Portuguese.

11. Longato MW, Castro PR, Keller KC, Ribas DIR. Efeito do Isostretching no equilíbrio de indivíduos amputados: um estudo de caso. Fisioter Mov. 2011;24(4):68996. Portuguese.

12. Cepeda CC, Rodacki ALF, Persc LN, Silva PP, Buba S, Dressler VF. Efeitos do método Isostretching sobre parâmetros morfológicos e sobre um conjunto de testes motores em idosas. Rev Bras Cineantropom Desempenho Hum. 2013;15(5):604-15. Portuguese.

13. Carvalho AR, Assini TCKA. Aprimoramento da capacidade funcional de idosos submetidos a uma intervenção por Isostretching. Rev Bras Fisioter. 2008;12(4):268-73. Portuguese. 
14. Macedo ACB, Gusso FR. Análise comparativa do alongamento do grupo muscular isquiotibial pelo método estático e pelo método Isostretching. Fisioter Mov. 2004;17(3):27-35. Portuguese.

15. Wilhelms F, Moreira NB, Barbosa PM, Vasconcellos PR, Nakayama GK, Bertolini GR. Análise da flexibilidade dos músculos da cadeia posterior mediante a aplicação de um protocolo específico de Isostretching. Arq Cienc Saude UNIPAR. 2010;14(1):63-71.

16. Barbosa EC, Peres CM, Lucca SR, Oliveira JI. Melhora da qualidade de vida e da dor referida em trabalhadores com síndrome do impacto após a aplicação do método Isostretching. Acta Fisiatr. 2012;19(3):17883. Portuguese.

17. Burkle AB, Shiraish, FO, Yabiku, FN. Aplicação do método Isostretching em pacientes mastectomizadas: série de casos. Rev Saude e Pesquisa. 2008;1(2):161-6.

18. Sá AF, Lima IAX. Os efeitos do método Isostretching na flexibilidade do paciente portador de escoliose idiopática. Ter Man. 2003;2(2):62-8.

19. Oliveira AP, Souza DE. Tratamento fisioterapêutico em escoliose através das técnicas de Isostretching e manipulações osteopáticas. Ter Man. 2004;2(3):94103. Portuguese.

20. Borghi AS, Antonini GM, Facci LM. Isostretching no tratamento da escoliose: série de casos. Saude e Pesquisa. 2008;1(2):167-71. Portuguese.

21. Monte-Raso VV, Ferreria PA, Carvalho MS, Rodrigues JG, Martins CC, Iunes DH. Efeito da técnica Isostretching no equilíbrio postural. Fisioter Pesqui. 2009;16(2):137-42. Portuguese.

22. 22. Moraes SMS, Mateus ECL. O método Isostretching no tratamento da hipercifose torácica. Fisio Bras. 2005;6(4):311-3. Portuguese.

23. Lopes PM, Yau MCH, Mackert TC, Facci L M. Isostretching no tratamento da lombalgia crônica. Fisio Bras. 2006;7(2):99-103. Portuguese.

24. Mann L, Kleinpaul JF, Weber P, Mota CB, Carpes FP. Efeito do treinamento de Isostretching sobre a dor lombar crônica: um estudo de caso. Motriz. 2009;15(1):50-60. Portuguese.
25. Durante H, Vasconcelos ECLM. Comparação do método Isostretching e cinesioterapia convencional no tratamento da lombalgia. Semina Cienc Biol Saude. 2009;30(1):83-90. Portuguese.

26. Macedo CSG, Debiagi PC, Andrade FM. Efeito do Isostretching na resistência muscular de abdominais, glúteo máximo e extensores de tronco, incapacidade e dor em pacientes com lombalgia. Fisioter Mov. 2010;23(1):113-20. Portuguese.

27. Tomé F, Ferreira CB, Cornelli RJB, Carvalgo AR. Lombalgia crônica: comparação entre duas intervenções na força inspiratória e capacidade funcional. Fisioter Mov. 2012;25(2):263-72.

28. Mota YL, Barreto SL, Bin PR, Simões HG, Campbell CSG. Respostas cardiovasculares durante a postura sentada da Reeducação Postural Global (RPG). Rev Bras Fisioter. 2008;12(3):161- 8. Portuguese.

29. Rosário JLP, Sousa A, Cabral CMN, João SMA, Marques AP. Reeducação postural global e alongamento estático segmentar na melhora da flexibilidade, força muscular e amplitude de movimento: um estudo comparativo. Fisioter Pesqui. 2008;15(1):12-8. Portuguese.

30. Souchard PE. Reeducação Postural Global: método do campo fechado. 4th ed. São Paulo: Cone; 2001. Portuguese.

31. Teixeira LAN, Ribeiro DCL. Tratamento para algias da coluna e retrações posturais utilizando o método de RPG - Reeducação Postural Global. Um estudo de caso. Ter Man. 2006;4(15):46-51. Portuguese.

32. Marques AP. Escoliose Tratada com reeducação postural global. Rev Fisioter Univ Sao Paulo. 1996;3(1):658. Portuguese.

33. Veronesi Jr JR, Tomaz C. Efeitos da reeducação postural global pelo método RPG/RFL na correção postural e no reequilíbrio muscular. Fisioter Mov. 2008;21(3):127-37. Portuguese.

34. Borges BLA. Flexibilidade de atletas de basquetebol submetidos à postura "em pé com inclinação anterior" do método de Reeducação Postural Global (RPG). Rev Bras Ci e Mov. 2006;14(4):39-46. Portuguese.

35. Silva EM, Andrade SC, Villar MJ. Evaluation of the effects of Postural Global Reeducation in patients with ankylosing spondylitis. Rheumatol Int. 2012;32:2155-63. 
36. Heredita EP, Rodrigues FF. O tratamento de pacientes com fibrose epidural pela Reeducação Postural GlobalRPG. Rev Bras Neurol. 2008;4(3):19-26. Portuguese.

37. Eduardo ACR, Oliveira CS, Oliveria LVF, Vilaverde AGJB. A RPG como modificadora da qualidade de vida de indivíduos portadores de lombalgia - um estudo piloto. Ter Man. 2006;4(15):12-6. Portuguese.

38. Di Ciaccio E, Polastri M, Bianchinie, Gasbarrini A. Herniated lumbar disc treated with Global Postural Reeducation. A middle-term evaluation. Eur Rev Med Pharmacol Sci. 2012;16:1072-7.

39. Bonetti F, Curti S, Mattioli S, Mugnai R, Vanti C, Violante FS, et al. Effectiveness of a 'Global Postural Reeducation' program for persistent Low Back Pain: a non-randomized controlled trial. BMC Musculoskelet Disord. 2010;11(285):2-12.

40. Price DD, Rafii A, Buckingham B. The validation of visual analogue scales ratio scale measures for chronic and experimental pain. Pain. 1983;17:45-56.

41. Nusbaum L, Natour J, Ferraz MB, Goldenberg J. Translation, adaptation and validation of the Roland-Morris questionnaire - Brazil Roland-Morris. Braz J Med Biol. Res. 2001;34(2):203-10.

42. Tritschler K. Medidas e avaliação em educação física e esportes de Barrow \& McGee. São Paulo: Manole; 2003. p. 339-40. Portuguese.
43. Guedes DP, Guedes JERP. Manual prático para avaliação em educação física. São Paulo: Manole; 2006. p. 123-5. Portuguese.

44. Marques AP. Cadeias musculares: um programa para ensinar avaliação fisioterapêutica global. 1st ed. São Paulo: Manole; 2000. p. 3-14. Portuguese.

45. Detsch C, Luz AMH, Candotti CT, Oliveira DS, Lazaron F, Guimarães LK, et al. Prevalência de alterações posturais em escolares do ensino médio em uma cidade no Sul do Brasil. Rev Panam Salud Publica. 2007;21(4):231-8. Portuguese.

46. Manek NJ, MacGregor AJ. Epidemiology of back disorders: prevalence, risk factor, and prognosis. Curr Opin Rheumatol. 2005;17(2):134-40.

47. Moreira CMC, Soares DRL. Análise da efetividade da reeducação postural global na protusão do ombro após a alta fisioterapêutica. Fisioter Mov. 2007;20(1):93-9. Portuguese.
Received: 07/16/2013

Recebido: 16/07/2013

Approved: 08/18/2015

Aprovado: 18/08/2015 
